\title{
Adult height after GH therapy in 188 Ullrich-Turner syndrome patients: results of the German IGLU Follow-up Study 2001
}

\author{
M B Ranke,C J Partsch ${ }^{1}$, A Lindberg ${ }^{2}$, H G Dörr ${ }^{3}$, M Bettendorf ${ }^{4}$, B P Hauffa ${ }^{5}$, H P Schwarz ${ }^{6}$, O Mehls ${ }^{4}$, S Sander $^{8}$, \\ N Stahnke ${ }^{7}$, H Steinkamp ${ }^{8}$, E Said ${ }^{8}$ and W Sippell ${ }^{1}$ for the German IGLU Follow-up Study \\ Paediatric Endocrinology Section, University Children's Hospital, Tübingen, Germany, ${ }^{1}$ Paediatric Endocrinology, University Children's Hospital, Kiel, \\ Germany, ${ }^{2}$ Pharmacia Corporation, Stockholm, Sweden, ${ }^{3}$ University Hospital for Children and Adolescents, Erlangen, Germany, ${ }^{4}$ University Children's \\ Hospital, Heidelberg, Germany, ${ }^{5}$ Department of Paediatric Endocrinology, University Hospital, Essen, Germany, ${ }^{6}$ University Children's Hospital, Munich, \\ Germany, ${ }^{7}$ University Children's Hospital, Hamburg, Germany and ${ }^{8}$ Pharmacia Corporation, Erlangen, Germany
}

(Correspondence should be addressed to Michael Ranke, Paediatric Endocrinology Section, University Children's Hospital, Hoppe-Seyler-Strasse 1, D-72076 Tübingen, Germany; Email: mlranke@med.uni-tuebingen.de)

\begin{abstract}
Objectives: We aimed to evaluate the factors influencing true adult height (HT) after long-term (from 1987 to 2000) GH treatment in Ullrich-Turner syndrome (UTS) based on modalities conceived in the 1980s.

Design: Out of 347 near-adult (>16 years) patients from 96 German centres, whose longitudinal growth was documented within KIGS (Pharmacia International Growth Database), 188 (45, X= $59 \%$; bone age $>15$ years) were available for further anthropometric measurements.

Results: At a median GH dose of 0.88 (10th/90th percentiles: 0.47/1.06) IU/kg per week, a gain of $6.0(-1.3 /+13) \mathrm{cm}$ above the projected adult height was recorded. Variables were recorded at GH start, after 1 year GH, puberty onset, and last visit on GH therapy. At these visits, the median ages were $11.7,12.7,14.2,16.6$ and 18.7 years; and median heights, $0.4,1.1,1.7,1.7$ and 1.3 SDS (UTS) respectively. Height gain $(\Delta \mathrm{HT})$ after GH discontinuation was $1.5 \mathrm{~cm}$. Total $\Delta \mathrm{HT}$ correlated $(P<$ $0.001)$ negatively with bone age and HT SDS at GH start, but positively with $\Delta$ HT after the first year, $\Delta \mathrm{HT}$ at puberty onset, and GH duration. Final HT correlated $(P<0.001)$ positively with HT at GH start, first-year $\Delta$ HT, and HT at puberty onset. Body mass index increased slightly $(P<0.05)$, with values at start and adult follow-up correlating highly $(R=0.70, P<0.001)$. No major side effects of GH occurred.

Conclusions: GH dosages conceived in the 1980s are safe but too low for most UTS patients. HT gain and height are determined by age and HT at GH start. Height gain during the first year on GH is indicative of overall height gain. After spontaneous or induced puberty, little gain in height occurs.
\end{abstract}

European Journal of Endocrinology 147 625-633

\section{Introduction}

The availability of recombinant human growth hormone (rhGH) since the 1980s has led to the exploration of its growth-promoting effects in various growth disorders. In a study of girls with Ullrich-Turner syndrome (UTS), Rosenfeld et al. were the first to prove that adult height could be improved by GH (1). In the 1980s, several similar studies were conceived, but their published results left doubts about the extent of height gain that could be achieved through GH therapy alone or in combination with oxandrolone (see Donaldson for a review (2)). In most of these studies, GH therapy was initiated at a relatively late age, with the $\mathrm{GH}$ dose being about 1.5 times the replacement doses used in treating GH deficiency. Recent studies, in which much higher doses were applied in younger patients, have confirmed that normalisation of height is a goal that can be achieved in UTS $(3,4)$. Multivariate analyses of the factors influencing height outcome have also shown that the most important factors are $\mathrm{GH}$ dose and age at the start of GH treatment (5). There is also accumulating evidence showing that oestrogen replacement for the induction of puberty limits further gains in height $(6-8)$. However, even though dosage appears to be one of the essential determinants of the growth effect, most studies have shown that the short- and long-term response to $\mathrm{GH}$ is rather variable. Our aim in conducting this follow-up study was to evaluate the long-term effects of $\mathrm{GH}$ in a large cohort 
of adult UTS patients. The source of data for our analysis derived from the documentation of patients who were primarily observed in a previous study on the efficacy and safety of rhGH (Genotropin) which began in 1986. Although a number of investigations were carried out in the follow-up study, our focus here will be on height outcome.

\section{Patients and methods}

Until January 2000, the Internationale Genotropin Langzeit-Untersuchung (IGLU) database, which is the German segment of Pharmacia International Growth Database (KIGS), documented UTS patients from 96 German centres, 347 of whom had reached nearadult height (age $>16$ years) at the time. The patients were initially included in a GH product trial (Genotropin) focusing on safety and efficacy, which began in 1986 in Germany. After GH was approved for the treatment of short stature in UTS, the data of these patients continued to be documented within the framework of KIGS, which was structured as a pharmaco-epidemiological survey. The last visit documented in IGLU marks the end of GH treatment and is referred to as the 'last IGLU visit'. In order to evaluate the results of treatment in terms of true adult height (bone age $>15$ years), the participating centres agreed on a standardised followup visit for patients belonging to this group. The follow-up was conducted according to a protocol approved by the Ethics Committee of the participating institutions, and written, informed consent was obtained at the time of the follow-up visit. A total of 188 patients returned for examination, their data providing the basis for our present analysis. Karyotype details were supplied by the referring physicians.

The anthropometric data were analysed according to previously described criteria (9). Reference values for height and midparent height (MPH) were taken according to the standards of Tanner et al. $(10,11)$. Weight and body mass index (BMI) were calculated on the basis of the British references of Freeman et al. (12). Birth weight and length were compared to the references of Niklasson et al. (13). We applied the height references for UTS of Ranke et al. (14) and weight and BMI references of Schweizer et al. (6). Standard deviation scores (SDS) for age were calculated.

On the model derived by Ranke et al. (15) we carried out the prediction of height velocity $(\mathrm{cm} /$ year $)$ and calculation of studentised residuals $(\mathrm{SR}=$ (observed height velocity (cm/year) minus predicted height velocity (cm/year)): residual of predicted height velocity $(\mathrm{cm} /$ year $))$ during the first year of treatment. Projected adult height (PAH) was calculated according to UTS standards of height (14). The onset of puberty was assumed either when breast stage II according to Tanner was observed or therapy with oestrogens was initiated. Bone age was rated according to Greulich \&
Pyle (16). The dose of GH was expressed in terms of IU/kg body weight $(\mathrm{BW})$ per week $(3 \mathrm{IU}=1 \mathrm{mg})$. All patients received daily injections of $\mathrm{GH}$. At the time of follow-up, all patients were receiving oestrogens or had spontaneously entered puberty, while in 15 patients this was not the case at the time-point of the last IGLU visit. Medians, 10th and 90th percentiles, Spearman correlation coefficients and Kruskal-Wallis tests were used to obtain $P$ values. A value of $P<0.01$ was considered significant.

\section{Results}

The distribution of karyotypes within the group of patients investigated $(n=188)$ is listed in Table 1 . We observed the $45, \mathrm{X}$ karyotype in $58 \%$ of patients, whereas in ten patients with complete female phenotype the karyotype $45, \mathrm{X} / 46, \mathrm{XY}$ was determined. Table 2 offers a selection of characteristics describing the group as a whole at various time-points, i.e. at the start of GH treatment, onset of spontaneous or induced puberty, the last IGLU visit and at the time of follow-up for this study. Information (medians) about the 159 patients of the original cohort $(n=347)$ who did not respond to the follow-up request is given for the relevant time-points in Table 2. In addition, the karyotype $45, \mathrm{X}$ was observed in $58 \%$ of this subset, and there was no statistically significant difference between any parameter $(P>0.1)$. As in other UTS cohorts, size at birth was lower by about 1 SDS, but parental height was normal. Treatment with GH started at a median age of $11+$ years. Height at start was insignificantly higher than that of the German UTS reference population (14). Consequently, the PAH was slightly higher than the average adult height for German UTS references (148.8 vs $146.3 \mathrm{~cm}$ ). The starting dosage of $\mathrm{GH}$ averaged $0.9 \mathrm{IU} / \mathrm{kg}$ BW per week and remained nearly constant (with the decrease being very insignificant) over the years. Height and weight for all patients at start and in comparison to UTS references

Table 1 UTS karyotypes represented in our study $(n=188)$.

\begin{tabular}{lrr}
\hline Karyotype & $\boldsymbol{n}$ & \% \\
\hline $45, \mathrm{X}$ & 110 & 58.5 \\
$45, \mathrm{X} / 46, \mathrm{XX}$ & 19 & 10.1 \\
$45, \mathrm{X} / 47, \mathrm{XXX}$ & 5 & 2.7 \\
$45, \mathrm{X} / 46, \mathrm{XX} / 47, \mathrm{XXX}$ & 2 & 1.1 \\
$45, \mathrm{X} / 46, \mathrm{X}, \mathrm{i}(\mathrm{Xq})$ & 16 & 8.5 \\
$45, \mathrm{X} / 46, \mathrm{X}, \mathrm{r}(\mathrm{X})$ & 5 & 2.7 \\
$46, \mathrm{X}, \mathrm{i}(\mathrm{Xq})$ & 9 & 4.8 \\
$46, \mathrm{X}, \mathrm{del}(\mathrm{Xq})$ & 1 & 0.5 \\
$46, \mathrm{X}, \mathrm{del}(\mathrm{Xp})$ & 1 & 0.5 \\
$45, \mathrm{X} / 46, \mathrm{X}, \mathrm{del}(\mathrm{Xq})$ & 3 & 1.6 \\
$45, \mathrm{X} / 46, \mathrm{X}, \mathrm{del}(\mathrm{Xp})$ & 1 & 0.5 \\
$45, \mathrm{X} / 46, \mathrm{XY}$ & 10 & 5.3 \\
Others & 6 & 3.2 \\
\hline
\end{tabular}


Table 2 Characteristics of UTS patients ( $n=188$ ) before, during and after GH therapy.

\begin{tabular}{|c|c|c|c|c|c|c|}
\hline \multirow[b]{3}{*}{ Variables } & \multicolumn{3}{|c|}{ Follow-up group $(n=188)$} & \multicolumn{3}{|c|}{ Group not seen for follow-up $(n=159)$} \\
\hline & \multirow[b]{2}{*}{ Median } & \multicolumn{2}{|c|}{ Percentiles } & \multirow[b]{2}{*}{ Median } & \multicolumn{2}{|c|}{ Percentiles } \\
\hline & & 10th & 90th & & 10th & 90th \\
\hline \multicolumn{7}{|l|}{ Background } \\
\hline Birth weight (SDS) & -1.1 & -2.9 & -0.1 & -1.3 & -2.8 & 0.3 \\
\hline Birth length (SDS) & -0.5 & -3.0 & 0.9 & -0.5 & -1.9 & 1.2 \\
\hline $\mathrm{MPH}(\mathrm{SDS})$ & 0.2 & -1.3 & 1.7 & 0.5 & -0.9 & 1.8 \\
\hline \multicolumn{7}{|l|}{ At GH start } \\
\hline Age (years) & 11.7 & 8.9 & 14.8 & 12.4 & 8.1 & 15.2 \\
\hline Bone age (years) & 10.0 & 7.3 & 12.5 & 10.5 & 7.0 & 13.0 \\
\hline Height (Tanner) (SDS) & -3.7 & -4.9 & -2.4 & -3.7 & -5.6 & -2.8 \\
\hline Height (SDS) & 0.4 & -1.1 & 1.8 & 0.3 & -1.0 & 1.6 \\
\hline $\mathrm{PAH}(\mathrm{cm})$ & 148.8 & 139.9 & 157.2 & 148.4 & 139.9 & 155.9 \\
\hline BMI (SDS) & 0.4 & -1.3 & 1.8 & 0.4 & -0.9 & 1.7 \\
\hline GH dose (IU/kg per week) & 0.88 & 0.47 & 1.06 & 0.84 & 0.47 & 1.03 \\
\hline \multicolumn{7}{|l|}{ After 1 year on $\mathrm{GH}$} \\
\hline Height (Ranke) (SDS) & 1.1 & -0.3 & 2.5 & 1.0 & -0.5 & 2.2 \\
\hline$\Delta \mathrm{HT}$ (Ranke) (SDS) & 0.7 & 0.3 & 1.2 & 0.6 & 0.2 & 0.9 \\
\hline At start of puberty & & $(n=173)$ & & & $(n=112)$ & \\
\hline Age (years) & 14.2 & 12.4 & 17.0 & 14.3 & 12.6 & 16.5 \\
\hline Bone age (years) & 12.0 & 10.5 & 13.5 & 12.5 & 11.0 & 13.5 \\
\hline Height (Ranke) (SDS) & 1.7 & 0.0 & 2.9 & 1.3 & 0.0 & 3.0 \\
\hline$\Delta \mathrm{HT}$ (Ranke) (SDS) & 1.1 & 0.4 & 2.2 & 0.9 & 0.1 & 2.1 \\
\hline Years on GH (years) & 2.4 & 0.8 & 5.0 & 2.1 & 0.5 & 5.3 \\
\hline \multicolumn{7}{|l|}{ At last IGLU visit } \\
\hline Age (years) & 16.6 & 14.7 & 19.3 & 16.5 & 15.3 & 19.2 \\
\hline Height $(\mathrm{cm})$ & 150.7 & 142.4 & 158.0 & 150.3 & 143.5 & 157.9 \\
\hline Height (Ranke) (SDS) & 1.7 & 0.0 & 3.0 & 1.7 & 0.1 & 2.9 \\
\hline BMI (SDS) & 0.7 & -1.0 & 2.2 & 0.7 & -0.5 & 2.3 \\
\hline$\Delta \mathrm{HT}$ (Ranke) (SDS) & 1.3 & 0.3 & 2.3 & 1.2 & 0.3 & 2.2 \\
\hline Years on GH (years) & 4.5 & 2.2 & 7.3 & 4.4 & 1.9 & 8.0 \\
\hline \multicolumn{7}{|l|}{ At follow-up } \\
\hline Age (years) & 18.7 & 16.0 & 23.6 & & & \\
\hline Height $(\mathrm{cm})$ & 152.2 & 144.0 & 159.8 & & & \\
\hline Height (Ranke) (SDS) & 1.3 & -1.1 & 2.6 & & & \\
\hline BMI (SDS) & 0.7 & -0.9 & 2.5 & & & \\
\hline$\Delta \mathrm{HT}$ (Ranke) (SDS) & 1.0 & -0.2 & 2.1 & & & \\
\hline Gain over PAH $(\mathrm{cm})$ & 6.0 & -1.3 & 13.0 & & & \\
\hline
\end{tabular}

are illustrated in Fig. 1a and b. The height increment ( $\Delta$ HT SDS for UTS) during the first year on GH averaged 0.7 SDS with 90\% exceeding 0.3 SDS. Puberty was observed after 2.4 years (median) on $\mathrm{GH}$, at an age of 14.2 years and a bone age of 12.0 years. By that time, height SDS exceeded the UTS references by 1.7 SDS and a total height gain of 1.1 SDS was recorded. In comparison to the height values for UTS references (SDS) there was, on average, no significant further height gain after puberty began. During the 2 years between the last IGLU visit and follow-up visit, we observed an average height gain of $1.5 \mathrm{~cm}$ in the total group $(n=188)$, whereas among the 39 patients with spontaneous puberty it averaged $1.1 \mathrm{~cm}$; in 134 patients with induced puberty after the last IGLU visit it averaged $1.4 \mathrm{~cm}$, and in the group of 15 patients who did not enter puberty before the last IGLU visit it averaged $3 \mathrm{~cm}$.
Table 3 shows the median values for characteristic parameters at the start of GH therapy, at the onset of puberty, the last IGLU visit and at follow-up, for the sub-groups of patients, i.e. those with spontaneous puberty $(n=39)$, induced puberty $(n=134)$ and no evidence of puberty during the course of the IGLU study $(n=15)$. There were no statistical differences between the auxological characteristics at the start of treatment and the outcome of $\mathrm{GH}$ therapy. In 35 patients, oxandrolone $(0.05 \mathrm{mg} / \mathrm{kg}$ per day) was introduced during GH treatment, however, the characteristics of these patients did not differ from the other groups (data not shown).

In order to evaluate the height outcome in terms of both gain in height ( $\Delta$ HT SDS UTS) and actual height achieved (centimetres), the variables were correlated with various parameters during the course of treatment. The results are listed in Table 4 and illustrated in Fig. 2. 

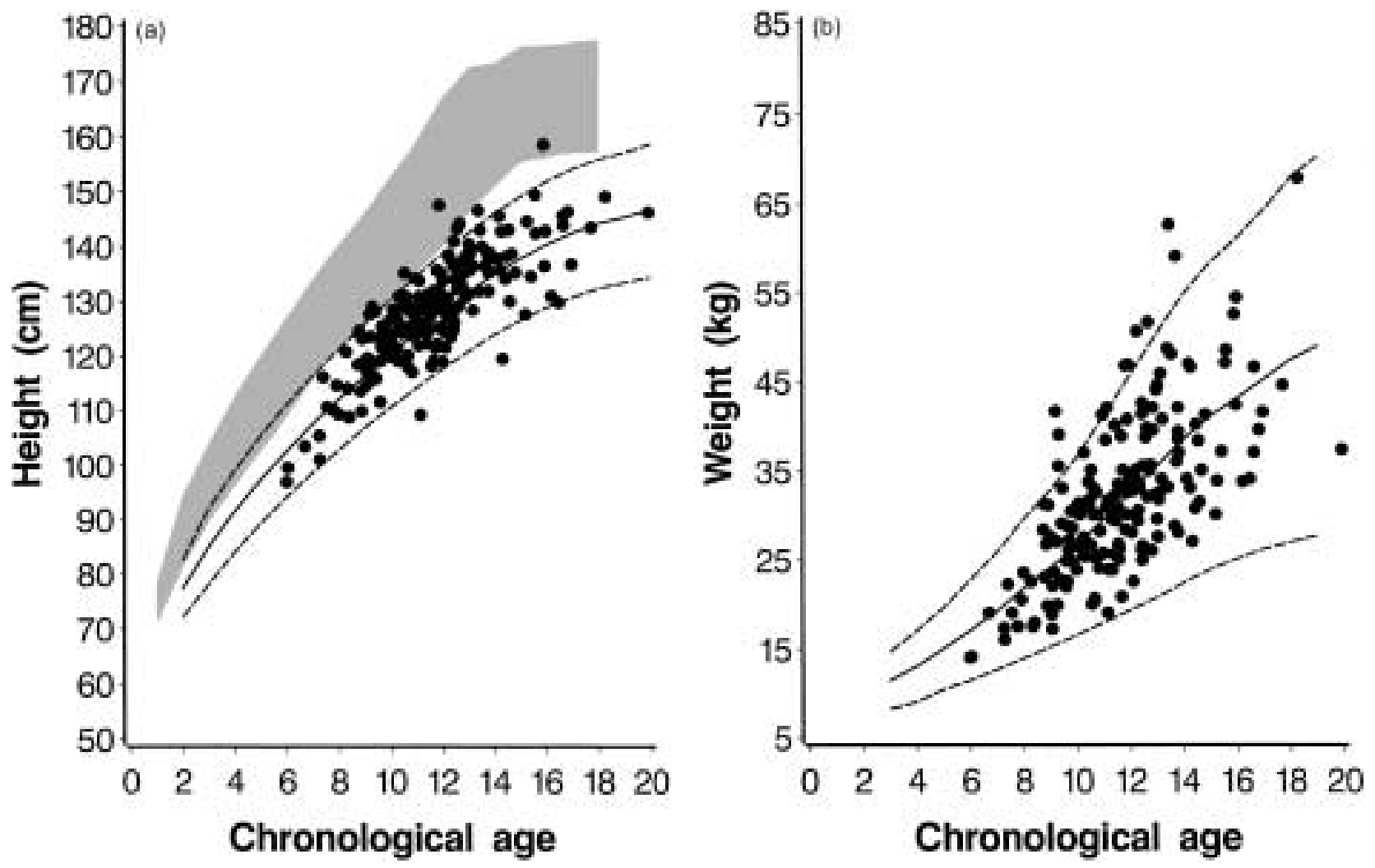

Figure 1 Height (a) and weight (b) of UTS patients $(n=188)$ at start of GH treatment in comparison to German UTS references. Broken lines indicate \pm 2 S.D. ranges; shaded areas indicate height range for normal girls.

Our results showed that the outcome variables of height correlated with variables before as well as during the first year of treatment. The gain in height (S.D.) and absolute height $(\mathrm{cm})$, however, did not correlate with the same predictors. The overall gain in height $(\Delta \mathrm{HT}$ SDS) was found to correlate with (a) auxological characteristics at the start of treatment (age, bone age (the lower, the better); height; BMI; HT minus $\mathrm{MPH}$ (= height distance to target height) (the smaller, the better)); (b) modalities of treatment (starting dose, mean dose, total dose (the higher, the better); years on GH (the longer, the better)); (c) auxological characteristics at onset of puberty (bone age (the lower, the better); total pre-pubertal growth (the more, the better)); and (d) first-year growth response (height velocity, studentised residual (the higher, the better)).

Adult height in absolute terms (centimetres) correlated with (a) auxological characteristics at start of treatment (height (the taller, the better)); (b) modalities of treatment (total dose (the higher, the better), years on GH (the longer, the better); (c) auxological characteristics at onset of puberty (height (the higher, the better); total pre-pubertal growth (the more, the better)); and (d) first-year growth response (height velocity, studentised residual (the higher, the better)). Height observed at follow-up and height predicted at start of therapy by means of a previously published descriptive model (17) correlated highly $(R=0.72$, $P<0.001)$.

None of the patients suffered from serious side-effects of GH therapy during follow-up. In particular, we did not observe the development of diabetes mellitus in any of the patients. In a sub-population of 90 patients, we had information on fasting blood glucose (BG), glycosylated haemoglobin $(\mathrm{HbA} 1 \mathrm{c})$, and total cholesterol (TC), this data being provided by the participating institutions. BG levels were $85.0 \pm 9.5 \mathrm{mg} / \mathrm{dl}$ (mean \pm S.D.), and, in one case, was $111 \mathrm{mg} / \mathrm{dl}$. HbAlc levels were $5.1 \pm 0.6 \%$ (mean \pm S.D.), with four patients exceeding $6.0 \%$ (one patient had $6.7 \%$ ). The TC levels were $174 \pm$ $27 \mathrm{mg} / \mathrm{dl}$ (mean \pm S.D.).

The BMI SDS were found to have increased between the start of GH treatment (median: 0.4 SDS) and followup (median: 0.7 SDS) when compared with normal references (see Table 2). The values at final height correlated positively $(R=0.70, P<0.001)$ with the level at the start of therapy. In comparison with Turnerspecific references (6), however, no increment in BMI was observed over time in the treated group (Fig. 3). 
Table 3 Differentiation of UTS patients according to pubertal type (in median values).

\begin{tabular}{|c|c|c|c|c|}
\hline \multirow[b]{2}{*}{ Variables } & \multirow[b]{2}{*}{ Total } & \multicolumn{3}{|c|}{ Groups } \\
\hline & & Spontaneous puberty & Induced puberty & No puberty \\
\hline Number & 188 & 39 & 134 & 15 \\
\hline $\begin{array}{l}\text { At GH start } \\
\text { Age (years) } \\
\text { Bone age (years) } \\
\text { Height (UTS) (SDS) } \\
\text { PAH (cm) } \\
\text { GH dose (IU/kg per week) }\end{array}$ & $\begin{array}{r}11.7 \\
10.0 \\
0.4 \\
148.8 \\
0.88\end{array}$ & $\begin{array}{c}11.5 \\
10.3 \\
0.6 \\
149.6 \\
1.00\end{array}$ & $\begin{array}{c}11.8 \\
10.0 \\
0.4 \\
148.9 \\
0.81\end{array}$ & $\begin{array}{c}11.3 \\
9.0 \\
0.0 \\
148.3 \\
0.96\end{array}$ \\
\hline $\begin{array}{l}\text { At start of puberty } \\
\text { Age (years) } \\
\text { Bone age (years) } \\
\text { Height (UTS) (SDS) } \\
\Delta \text { HT (Ranke) (SDS) } \\
\text { Years on GH (years) }\end{array}$ & $\begin{array}{r}14.2 \\
12.0 \\
1.7 \\
1.1 \\
2.4\end{array}$ & $\begin{array}{r}14.2 \\
12.6 \\
1.8 \\
1.2 \\
2.6\end{array}$ & $\begin{array}{r}14.3 \\
12.0 \\
1.5 \\
1.1 \\
2.4\end{array}$ & $\begin{array}{l}- \\
- \\
- \\
- \\
-\end{array}$ \\
\hline $\begin{array}{l}\text { At last IGLU visit } \\
\text { Age (years) } \\
\text { Height (cm) } \\
\text { Height (UTS) (SDS) } \\
\text { Years on GH (years) }\end{array}$ & $\begin{array}{r}16.6 \\
150.7 \\
1.7 \\
4.5\end{array}$ & $\begin{array}{r}16.9 \\
151.3 \\
1.7 \\
5.1\end{array}$ & $\begin{array}{r}16.5 \\
150.9 \\
1.8 \\
4.5\end{array}$ & $\begin{array}{r}15.6 \\
147.8 \\
1.6 \\
3.4\end{array}$ \\
\hline $\begin{array}{l}\text { At follow-up } \\
\text { Age (years) } \\
\text { Height (cm) } \\
\text { Height (Ranke) (SDS) } \\
\Delta \text { HT (Ranke) (SDS) } \\
\text { Gain over PAH (cm) }\end{array}$ & $\begin{array}{r}18.7 \\
152.2 \\
1.3 \\
1.0 \\
6.0\end{array}$ & $\begin{array}{r}19.5 \\
152.4 \\
1.3 \\
0.8 \\
5.0\end{array}$ & $\begin{array}{r}18.5 \\
152.3 \\
1.3 \\
1.0 \\
6.1\end{array}$ & $\begin{array}{r}18.8 \\
150.8 \\
1.5 \\
1.1 \\
7.0\end{array}$ \\
\hline
\end{tabular}

Table 4 Simple linear correlation of height outcome and patient characteristics during observation.

\begin{tabular}{|c|c|c|c|c|c|c|}
\hline \multirow[b]{2}{*}{ Variable } & \multicolumn{3}{|c|}{$\Delta \mathrm{HT}$ SDS (UTS) } & \multicolumn{3}{|c|}{ Adult HT (cm) } \\
\hline & $n$ & $R$ & $P$ & $n$ & $R$ & $P$ \\
\hline $\begin{array}{l}\text { At GH start } \\
\text { Age (years) } \\
\text { Bone age (years) } \\
\text { Height (UTS) (SDS) } \\
\text { HT MPH (SDS) } \\
\text { BMI (SDS) } \\
\text { GH dose (IU/kg per week) }\end{array}$ & $\begin{array}{l}188 \\
162 \\
188 \\
178 \\
188 \\
188\end{array}$ & $\begin{array}{l}-0.274 \\
-0.530 \\
-0.56 \\
-0.284 \\
-0.268 \\
0.217\end{array}$ & $\begin{array}{l}<0.001 \\
<0.001 \\
<0.001 \\
<0.001 \\
<0.001 \\
<0.003\end{array}$ & $\begin{array}{l}188 \\
162 \\
188 \\
178 \\
188 \\
188\end{array}$ & $\begin{array}{r}-0.048 \\
-0.014 \\
0.627 \\
-0.037 \\
0.053 \\
0.015\end{array}$ & $\begin{aligned} & N S \\
& \text { NS } \\
&<0.001 \\
& \text { NS } \\
& \text { NS } \\
& \text { NS }\end{aligned}$ \\
\hline $\begin{array}{l}\text { First year on GH } \\
\Delta H T \text { (SDS) } \\
\text { Studentised residual }\end{array}$ & $\begin{array}{l}188 \\
102\end{array}$ & $\begin{array}{l}0.456 \\
0.375\end{array}$ & $\begin{array}{l}<0.001 \\
<0.001\end{array}$ & $\begin{array}{l}188 \\
102\end{array}$ & $\begin{array}{l}0.243 \\
0.232\end{array}$ & $\begin{array}{l}0.001 \\
0.019\end{array}$ \\
\hline $\begin{array}{l}\text { At start of puberty } \\
\text { Age (years) } \\
\text { Bone age (years) } \\
\text { Height (UTS) (SDS) } \\
\text { HT MPH (SDS) }\end{array}$ & $\begin{array}{l}133 \\
125 \\
133 \\
125\end{array}$ & $\begin{array}{r}0.103 \\
-0.242 \\
-0.082 \\
0.004\end{array}$ & $\begin{array}{l}\text { NS } \\
0.007 \\
\text { NS } \\
\text { NS }\end{array}$ & $\begin{array}{l}133 \\
125 \\
133 \\
125\end{array}$ & $\begin{array}{l}0.096 \\
0.105 \\
0.745 \\
0.136\end{array}$ & $\begin{array}{l}\text { NS } \\
\text { NS } \\
<0.001 \\
\text { NS }\end{array}$ \\
\hline $\begin{array}{l}\text { Pre-pubertal } \\
\Delta H T \text { (SDS) } \\
\text { Mean GH (IU/kg per week) }\end{array}$ & $\begin{array}{l}133 \\
125\end{array}$ & $\begin{array}{l}0.682 \\
0.035\end{array}$ & $\begin{array}{c}<0.001 \\
\text { NS }\end{array}$ & $\begin{array}{l}133 \\
133\end{array}$ & $\begin{array}{r}0.279 \\
-0.111\end{array}$ & $\begin{array}{l}0.001 \\
\text { NS }\end{array}$ \\
\hline $\begin{array}{l}\text { At end of follow-up } \\
\text { Age (years) } \\
\text { Duration of GH therapy (years) } \\
\text { Total GH dose (IU/kg per week) } \\
\text { Mean GH dose (IU/kg per week) }\end{array}$ & $\begin{array}{l}188 \\
188 \\
188 \\
188\end{array}$ & $\begin{array}{r}-0.191 \\
0.465 \\
0.380 \\
0.183\end{array}$ & $\begin{array}{r}0.008 \\
<0.001 \\
<0.001 \\
0.012\end{array}$ & $\begin{array}{l}188 \\
188 \\
188 \\
188\end{array}$ & $\begin{array}{r}0.130 \\
0.264 \\
0.264 \\
-0.076\end{array}$ & $\begin{array}{l}\text { NS } \\
0.035 \\
<0.001 \\
\text { NS }\end{array}$ \\
\hline
\end{tabular}



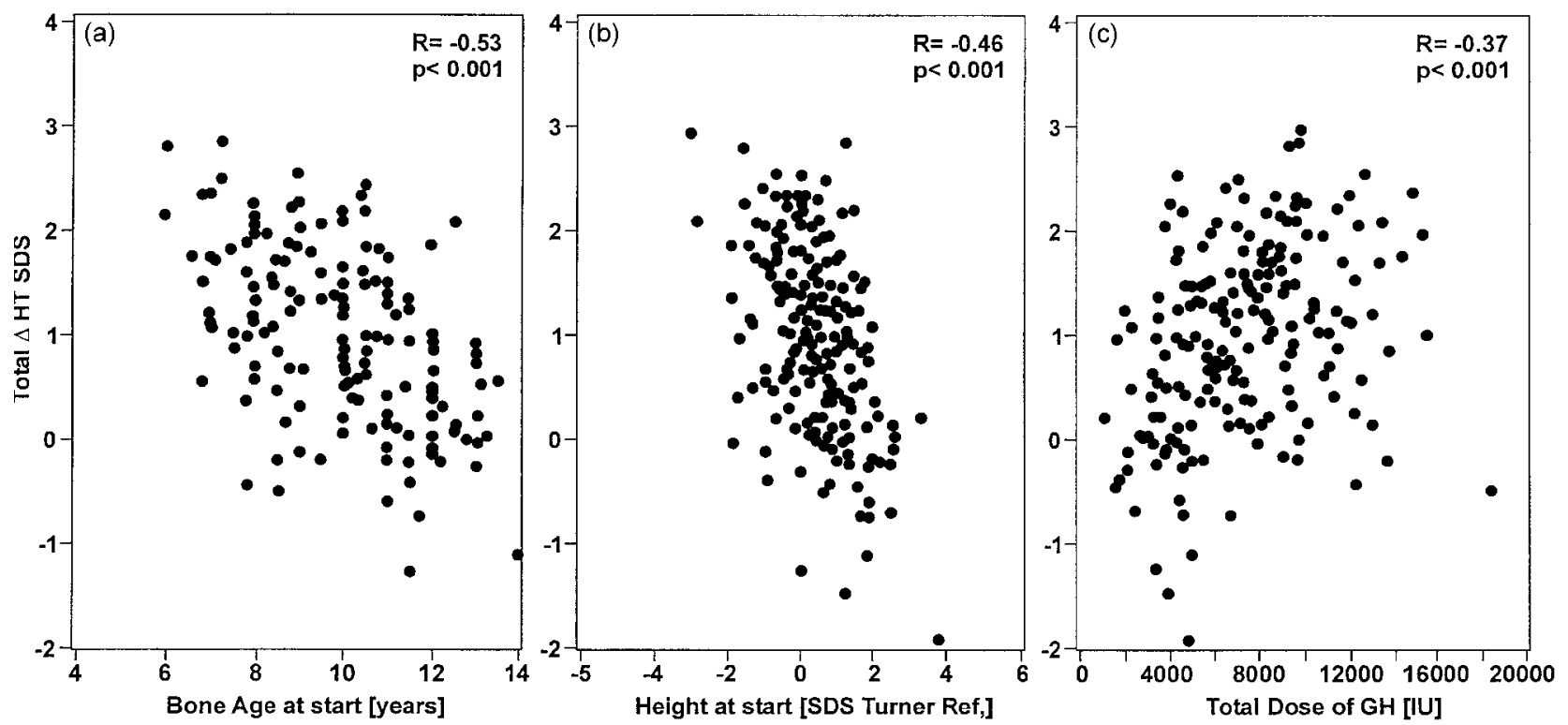

Figure 2 Factors influencing total height gain, showing correlation between total $\Delta \mathrm{HT}$ (SDS) and (a) bone age at GH start, (b) height at start (SDS Turner references), and (c) total dose of GH (IU).

\section{Discussion}

It has become general practice in many countries to treat UTS patients with GH in order to improve short

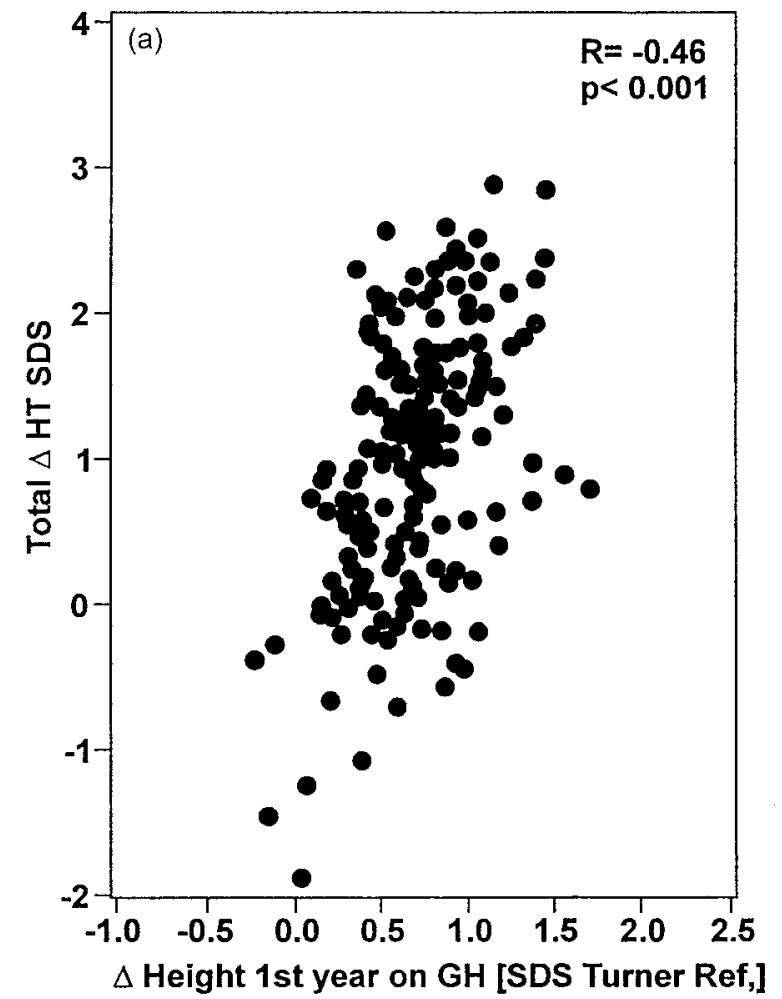

stature. There are, however, few reports on the adult height outcome of long-term GH treatment $(2,18-$ 24). It must be remembered that the final height gained reflects treatment concepts that were developed

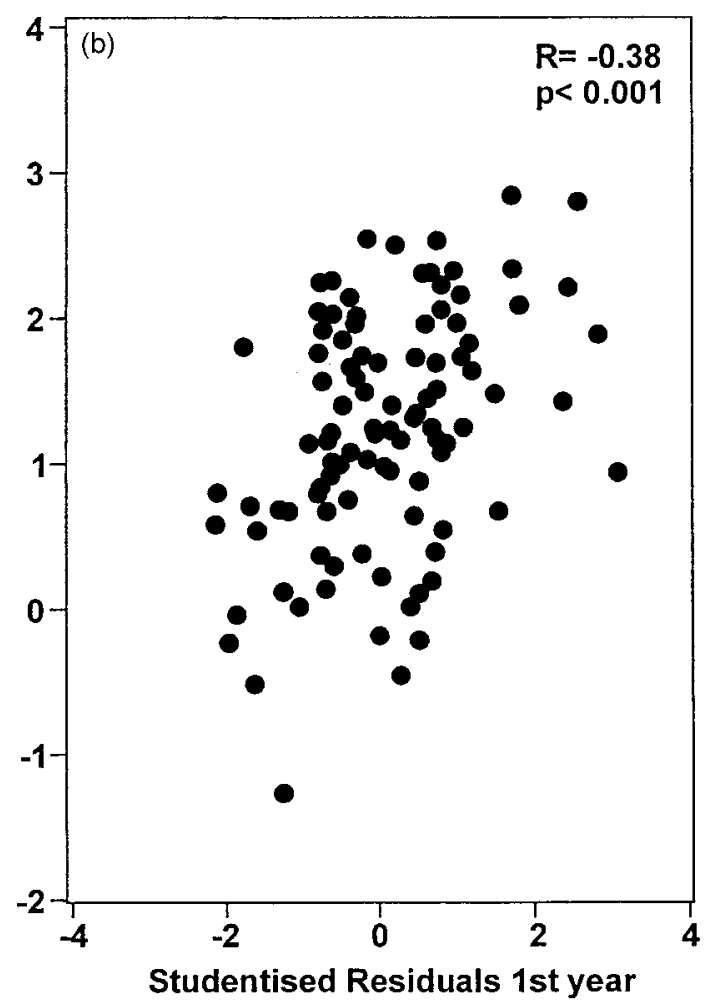

Figure 3 Factors influencing total height gain, showing correlation between total $\Delta \mathrm{HT}$ (SDS) and (a) first-year $\Delta \mathrm{HT}$ (SDS Turner references), and (b) first-year studentised residuals. 
almost two decades ago. Since that time, several determining factors relating to the short-term response to GH have been identified (25), the most significant among them being the age at $\mathrm{GH}$ start (the younger, the better), and the GH dose (the higher, the better). In contrast, relatively little knowledge is available about the factors determining the development of adult height (9). An analysis of patients treated with intermediary $\mathrm{GH}$ doses (e.g. <1.0 IU/kg per week) seems particularly important, since it appears that not all UTS patients necessarily need to be treated with high GH doses; conversely, long-term GH treatment may not be suitable at all in certain cases.

The present study, drawing on data from a national cohort of patients treated with one brand of GH, represents the first large study where a follow-up of true adult height was done after GH treatment ended. The genetic composition of the cohort investigated concurs with other large series (6). The advanced age at start of GH treatment partly reflects the age at the time UTS was diagnosed but also involves a certain bias resulting from the fact that final height is achieved within a shorter period of treatment. The height at start of GH is only slightly higher than that of historical German references (14). The $\mathrm{GH}$ dose was within a rather narrow range of $0.45-1.1 \mathrm{IU} / \mathrm{kg}$ per week, which is similar to other studies conceived in the 1980s (2).

The characteristics at start of GH, after 1 year on GH, at puberty onset and at the time of the last regular KIGS visit, were not different in the 159 patients who did not return for the follow-up visit, which indicates that there is no selection bias for the 188 patients analysed. The availability of data, however, made it feasible to prove true adult height only in the latter patients.

It is interesting to note that only 15 of 188 patients were not pubertal and had not received oestrogen replacement even at the time of the last IGLU visit. The oestrogen replacement was, on the average, delayed until the patient reached approximately 14 years of age, i.e. corresponding to a bone age of 12 years. This may reflect the prevailing therapeutical approach of physicians in view of the doubtful magnitude of the GH effect on growth.

The late introduction of oestrogens appears to be a decisive factor influencing height outcome in patients treated with similar doses of GH, as other investigations $(6,26)$ have shown. Since the spread of age at pubertal onset was, however, relatively narrow, our data do not allow a complex multiple regression analysis relating puberty with adult height in UTS.

It is remarkable that we observed only an average gain of $1.5 \mathrm{~cm}$ between the last IGLU visit and the follow-up after 2 years. These findings are valuable in terms of counselling as they allow realistic expectations relating to the growth process after $\mathrm{GH}$ treatment ends. The present study provides further, strong support for the thesis that GH treatment offers UTS patients the means to achieve a substantial gain in height. Our results also confirm, however, that the total gain in height over projected height proved to be variable, a fact that was also true for the height outcome in terms of absolute height. The median gain in height above PAH averaged $6.0 \mathrm{~cm}$ after 4.5 years on $\mathrm{GH}$, which correlates with the results found in similar cohorts that received comparable GH doses (2). The major correlates of height gain were bone age (negative) and height SDS (UTS) (negative) at start of GH, the first-year growth during $\mathrm{GH}$ therapy (positive), the overall pre-pubertal height gain $(\Delta \mathrm{HT}$ SDS) (positive), GH dosing (positive), and the duration of treatment (positive).

It can be assumed that duration of treatment is a function of age at $\mathrm{GH}$ start as well as the time at which the closure of epiphyses (puberty) began. It is realistic to expect that the pre-pubertal height gain positively correlates with overall height gain, since the onset of puberty occurred towards the end of growth, and was later in the UTS patients. It is remarkable to note, however, that first-year growth and responsiveness to treatment (as expressed in terms of the studentised residual) show a high correlation with overall height gain. This appears to indicate that the response to $\mathrm{GH}$ is a quality that is specific to each individual patient. In practical terms, this would mean that a girl whose first-year height gain is below 0.4 SDS (UTS) and with a studentised residual below -1.0 is very unlikely to have a total gain in height of more than $6 \mathrm{~cm}$ (= 1.0 SDS UTS) on a GH dose of $0.9 \mathrm{IU} / \mathrm{kg}$ per week. While the gain in height is greater if a UTS patient is relatively short, the absolute height outcome is better in cases of UTS girls who are already relatively tall. This means that a tall UTS girl is not likely to gain much height through low-dose GH treatment, but will likely reach the PAH with high probability. If the method of height projection were also a truly precise measure in patients with extremes of height for UTS $(<-1.0$ SDS; $>+1.0$ SDS $)$, it would follow that children whose $\mathrm{PAH}$ is within the normal range need not be treated with GH. It is remarkable that the analysis of data concerning low-dose $\mathrm{GH}$ ranges shows that dosage is important for the short-term as well as long-term gain in height, but to a lesser degree for the achievement of absolute height. Following this reasoning, it can be presumed that in relatively tall children, in whom the outcome in height tends to be favourable, only higher doses than applied here are probably necessary in order to be effective. These findings indicate that an increase in the GH dose, in order to induce a response (cm/year; $\Delta \mathrm{HT}$ SDS), can probably be avoided, thus reducing the high costs of GH therapy in some UTS patients. Studies in which there is no control of $\mathrm{GH}$ dosage may also lead to false conclusions, because observations of the response - rather than responsiveness to GH - may lead to higher $\mathrm{GH}$ doses among poor responders. Thus, in terms of the final height outcome, our study shows 
that the responsiveness during the first year on $\mathrm{GH}$ is important. Since the aim of treating short stature in UTS is to achieve the normalisation of height and, at the same time, induce the normal timing and progression of puberty, the therapy needs to focus on the first pre-pubertal years.

Future studies should aim to compare the results of continuous GH treatment with those of interrupted treatment (such as the type suggested for the observation of small-for-gestational-age patients (27)), in which various dose levels are applied, and in which the early response as well as responsiveness to $\mathrm{GH}$ are taken into consideration.

\section{Acknowledgements}

The participating investigators are as follows:

H I Akkurt (Hamburg), W Andler (Datteln), M Becker (Wiesbaden), H J Böhles (Frankfurt), J Brämswig (Münster), O Butenandt (Munich), M Bettendorf (Heidelberg), H G Dörr (Erlangen), J H H Ehrich (Hannover), B Erxleben (Potsdam), B Griefahn (Greifswald), A Grüters (Berlin), K Hartmann (Frankfurt), B P Hauffa (Essen), F Haverkamp (Bonn), W Hecker (Stuttgart), U Heinrich (Heidelberg), G K Hinkel (Dresden), O Hiort (Lübeck), R Holl (Giessen), J Homoki (Ulm), G Horneff (Halle), U Irle (Bremen), R Johs (Braunschweig), C Jourdan (Herford), E Keller (Leipzig), J Kerstan (Hildesheim), E Korsch (Cologne), J Kreuder (Giessen), H P Krohn (Wilhelmshaven), F Krull (Aurich), D Kunze (Munich), M Lakomek (Göttingen), D Lenz (Bremerhaven), U Leuthold (Siegen), M Mix (Rostock), K Mohnike (Magdeburg), M Morlot (Hannover), R Mühlenberg (Krefeld), H Müller (Würzburg), C J Partsch (Kiel), M Pavlovic (Freiburg), K Rager (Bad Mergentheim), M B Ranke (Tuebingen), W Rauh (Trier), H J Rickers (Osnabrück), B Schenk (Schwerin), D Schnabel (Berlin), E Schönau (Cologne), H P Schwarz (Munich), G Simic-Schleicher (Bremen), W G Sippell (Kiel), N Stahnke (Hamburg), M Teufel (Böblingen), W Tillmann (Minden), B Tittel (Dresden), U Tuschy (Erfurt), K P Ullrich (Gotha), W von Petrikowsky (Freiburg), H P Weber (Lüdenscheid), K Wesseler (Detmold), R P Willig (Hamburg), J Wintgens (Mönchengladbach) and M Witsch (Mannheim).

\section{References}

1 Rosenfeld RG, Attie KM, Frane J, Brasel JA, Burstein S, Cara JF et al. Growth hormone therapy of Turner's syndrome: beneficial effect on adult height. Journal of Pediatrics 1998132 319-324.

2 Donaldson MDC. Growth hormone therapy in Turner syndrome - current uncertainties and future strategies. Hormone Research 199748 (Suppl 5) 35-44.

3 Sas T, de Waal W, Mulder P, Houdijk M, Jansen M, Reeser M et al. Growth hormone treatment in children with short stature born small for gestational age: 5year results of a randomized, doubleblind, dose-response trial. Journal of Clinical Endocrinology and Metabolism 199984 3064-3070.
4 Carel JC, Mathivon L, Gendrel C, Ducret JP \& Chaussain JL. Near normalization of final height with adapted doses of growth hormone in Turner's syndrome. Journal of Clinical Endocrinology and Metabolism $1998 \mathbf{8 3} 1462-1466$.

5 Ranke MB, Price DA, Maes M, Albertsson-Wikland K \& Lindberg A. Factors influencing final height in Turner syndrome following GH treatment: results of the Kabi International Growth Study (KIGS). In Turner Syndrome in a Life Span Perspective: Research and Clinical Aspects, International Congress Series 1089 Edition, pp 161-168. Eds K Albertsson-Wikland \& MB Ranke. Amsterdam: Elsevier, 1995.

6 Schweizer R, Ranke MB, Binder G, Herdach F, Zapadlo M, Grauer ML et al. Experience with growth hormone therapy in Turner syndrome in a single centre: low total height gain, no further gains after puberty onset and unchanged body proportions. Hormone Research $200053228-238$.

7 Chernausek SD, Attie KM, Cara JF, Rosenfeld RG \& Frane J. Growth hormone therapy of Turner syndrome: the impact of age of estrogen replacement on final height. Genentech, Inc., Collaborative Study Group. Journal of Clinical Endocrinology and Metabolism 200085 2439-2445.

8 Cacciari E \& Mazzanti L. Final height of patients with Turner's syndrome treated with growth hormone $(\mathrm{GH})$ : indications for GH therapy alone at high doses and late estrogen therapy. Italian Study Group for Turner Syndrome. Journal of Clinical Endocrinology and Metabolism 199984 4510-4415.

9 Ranke MB, Lindberg A, Chatelain P, Cutfield W, AlbertssonWikland K, Wilton P et al. Turner Syndrome: demography, auxology and growth during growth hormone therapy in KIGS. In Growth Hormone Therapy in KIGS - 10 Years' Experience, pp 245-258. Eds MB Ranke \& P Wilton. Heidelberg: Johann Ambrosius Barth, 1999.

10 Tanner JM, Whitehouse RH \& Takaishi M. Standards from birth to maturity for height, weight, height velocity, and weight velocity: British children, 1965. I. Archives of Diseases in Childhood 1966 41 454-471.

11 Tanner JM, Whitehouse RH \& Takaishi M. Standards from birth to maturity for height, weight, height velocity, and weight velocity: British children, 1965. II. Archives of Diseases in Childhood 1966 41 613-635.

12 Freeman JV, Cole TJ, Chinn S, Jones PR, White EM \& Preece MA. Cross sectional stature and weight reference curves for the UK, 1990. Archives of Diseases in Childhood 199573 17-24.

13 Niklasson A, Ericson A, Fryer JG, Karlberg J, Lawrence C \& Karlberg P. An update of the Swedish reference standards for weight, length and head circumference at birth for given gestational age (1977-1981). Acta Paediatrica Scandinavica 199180 $756-762$.

14 Ranke MB, Stubbe P, Majewski F \& Bierich JR. Spontaneous growth in Turner's syndrome. Acta Paediatrica Scandinavica (Suppl) $198834322-30$.

15 Ranke MB, Lindberg A, Chatelain P, Wilton P, Cutfield W, AlbertssonWikland $\mathrm{K}$ et al. Predicting the response to recombinant human growth hormone in Turner syndrome: KIGS models. Acta Paediatrica Scandinavica (Suppl) $1999433122-125$.

16 Greulich W \& Pyle S. Radiographic Atlas of the Skeletal Development of the Hand and Wrist, edn 2. Stanford, CA: Stanford University Press, 1959.

17 Ranke M, Lindberg A, Chatelain P, Wilton P, Cutfield W, Albertsson-Wikland $\mathrm{K}$ et al. Prediction of long-term response to recombinant human growth hormone in Turner syndrome: development and validation of mathematical models. Journal of Clinical Endocrinology and Metabolism $2000854212-4218$.

18 Heinrichs C, De Schepper J, Thomas M, Massa G, Craen M, Malvaux P, Ernoul C et al. Final height in 46 girls with Turner syndrome treated with growth hormone in Belgium: evaluation of height recovery and predictive factors. In Turner Syndrome in a Life Span Perspective: Research and Clinical Aspects, International Congress Series 1089 Edition, pp 137-147. Eds K AlbertssonWikland \& MB Ranke. Amsterdam: Elsevier, 1995. 
19 Massa G, van den Broeck J, Attanasio A \& Wit JM. Final height results of the Lilly European Turner studies. In Turner Syndrome in a Life Span Perspective: Research and Clinical Aspects, International Congress Series 1089 Edition, pp 155-159. Eds K Albertsson-Wikland \& MB Ranke. Amsterdam: Elsevier, 1995.

20 Nilsson KO, Albertsson-Wikland K, Alm J, Aronson S, Gustafsson J, Hagenäs L et al. Growth promoting treatment in girls with Turner syndrome: final height results according to three different Turner syndrome standards. In Turner Syndrome in a Life Span Perspective: Research and Clinical Aspects, International Congress Series 1089 Edition, pp 89-94. Eds K Albertsson-Wikland \& MB Ranke. Amsterdam: Elsevier, 1995.

21 Rochiccioli P \& Chaussain JL. Final height in patients with Turner syndrome treated with growth hormone $(n=117)$. In Turner Syndrome in a Life Span Perspective: Research and Clinical Aspects, International Congress Series 1089 Edition, pp 123-128. Eds K Albertsson-Wikland \& MB Ranke. Amsterdam: Elsevier, 1995.

22 Stahnke N, Attanasio A, van den Broeck J, Partsch CJ \& Zeisel HJ. GH treatment studies to final height in girls with Turner syndrome - the German experience. In Turner Syndrome in a Life Span Perspective: Research and Clinical Aspects, International Congress Series 1089 Edition, pp 94-103. Eds K Albertsson-Wikland \& MB Ranke. Amsterdam: Elsevier, 1995.

23 Takano K, Ogawa M, Okada Y, Tanaka T, Tachibana K \& Hizuka N and the members of the Committee for the Treatment of Turner Syndrome. Final height and long-term effects after growth hormone therapy in Turner syndrome: results of a 6-year multicentre study in Japan. In Turner Syndrome in a Life Span Perspective:
Research and Clinical Aspects, International Congress Series 1089 Edition, pp 113-121. Eds K Albertsson-Wikland \& MB Ranke. Amsterdam: Elsevier, 1995.

24 Tillmann V, Price DA, Bucknall JL \& Clayton PE. Experience within the Manchester Growth Clinic of growth hormone treatment of girls with Turner syndrome: the influence of duration of treatment on final height. In Turner Syndrome in a Life Span Perspective: Research and Clinical Aspects, International Congress Series 1089 Edition, pp 149-154. Eds K Albertsson-Wikland \& MB Ranke. Amsterdam: Elsevier, 1995.

25 Ranke MB \& Lindberg A. Treatment with growth hormone in Turner syndrome with the aid of prediction models. In Optimizing Health Care for Turner Patients in the 21st Century, pp 163-168. Eds P Saenger \& AM Pasquino. Amsterdam: Elsevier, 2000.

26 Wilson DM, Dotson RJ, Neely EK, Cohen P, Hintz RL \& Rosenfeld RG. Effects of estrogen on growth hormone following clonidine stimulation. American Journal of Diseases of Children 1993147 63-65.

27 Ranke MB \& Preece MA. Growth hormone treatment in short children born small for gestational age: from controversy towards consensus. Hormone Research 199748 (Suppl 1) 72-74.

Received 6 March 2002

Accepted 22 July 2002 